Joelle Vuille* and William C. Thompson

\title{
An American Advantage? How American and Swiss Criminal Defense Attorneys Evaluate Forensic DNA Evidence
}

DOI 10.1515/ice-2016-0002

Published online November 18, 2016

Abstract: Critics of the American system of justice sometimes perceive "inquisitorialism" as an attractive alternative. In this article we will report a comparative study investigating the way forensic DNA evidence is handled in criminal prosecutions in the Swiss and American systems, focusing particularly on the behavior of criminal defense lawyers. We will argue that the successes and failures of American and Swiss lawyers in this context offer important insights into the relative strengths and limitations of adversarial and non-adversarial legal systems.

Keywords: expert evidence, adversarial, inquisitorial, forensic DNA analysis

\section{Introduction}

Critics of the American system of justice sometimes perceive the non-adversarial ${ }^{1}$ legal systems found in many European countries as an attractive alternative - a cure for various perceived shortcomings of the American system (Frase, 1990; Langbein, 1981; Pizzi, 2000; Slobogin, 2013; van Koppen \& Penrod, 2003; Volkmann-Schluck, 1981; Weinreb, 1977). In European practice, they see a lesser

1 We follow Damaška (1973) in describing modern continental European criminal procedure as non-adversarial rather than inquisitorial, reserving the latter term for the medieval ancestors of current systems. We recognize that modern European systems contain some adversarial elements. Systems borrow from one another, creating "shades of grey" (Pizzi, 1997, p. 847) in the continuum of non-adversarial to adversarial. Many Europeans describe their current system as "mixed" and the two models seem to be slowly converging in many respects (Bradley, 1996), a trend which has, in Europe, been reinforced by the influence of the European Court of Human Rights (Jackson, 2005).

*Corresponding author: Joelle Vuille, Universite de Neuchatel Faculte de Droit, 1er-Mars 26, Neuchatel, NE 2000, Switzerland, E-mail: joelle.vuille@unine.ch

http://orcid.org/0000-0003-1786-991X

William C. Thompson, Department of Criminology, Law \& Society and School of Law, University of California, Irvine, CA, USA, E-mail: william.thompson@uci.edu 
potential for bias in the presentation of evidence (Lind \& Walker, 1979; Sheppard \& Vidmar, 1980; Thibaut \& Walker, 1978) and hence a lower risk of false convictions (Huff \& Killias, 2008). With regard to scientific evidence, they see the nonadversarial systems, in which experts are appointed and directed by neutral magistrates or courts, as a possible remedy for the polarization, partisanship, and acrimony that can arise in an adversarial system where experts are appointed and presented by the parties (Alschuler, 1997; Frase \& Weigend, 1995; Frase, 1990; Goldstein, 1973; Langbein \& Weinreb, 1978; Langbein, 1977, 1981; Schlesinger, 1976; Volkmann-Schluck, 1981). There have been efforts to test the relative merits of adversarial and non-adversarial approaches to adjudication using trial simulations (Lind \& Walker, 1979; Lind, Thibaut, \& Walker, 1973; Sevier, 2014; Sheppard \& Vidmar, 1980). There has been relatively little research, however, on how (and how well) non-adversarial legal systems deal with scientific evidence relative to adversarial systems.

In this article we will report a comparative study focusing on the way forensic DNA evidence is handled in criminal prosecutions in the Swiss and American systems. ${ }^{2}$ Relying on interviews and participant observations we offer a detailed account of the treatment of DNA evidence in the two systems, focusing particularly on the behavior of criminal defense lawyers who are expected in both systems to help expose limitations and problems with evidence against the accused.

Forensic DNA evidence provides an interesting point of comparison between the two systems for several reasons. It is a powerful type of evidence that is playing an increasingly important role in both systems. The same type of DNA evidence (produced by the same methods) is used in the two systems for the same purposes - typically for identification of the source of biological samples associated with criminal activity. Importantly, it is a type of evidence that poses challenges for the legal system due to its complexity. We will argue that the successes and failures of American and Swiss lawyers in dealing with DNA evidence offer important insights into the relative strengths and limitations of the American and Swiss legal systems, which may well apply to adversarial and non-adversarial legal systems more generally.

2 While we recognize that there is considerable diversity among both adversarial and nonadversarial legal systems, we will argue that the Swiss system is typical of non-adversarial systems in a number of respects that are important for our analysis. Specifically, the Swiss system puts a great emphasis on pre-trial investigations, on the creation of a common investigative record accessible to all parties, and on the role of a neutral magistrate to conduct the investigation. It is also typical in its use of scientific expertise, adduced almost exclusively in the form of court-appointed specialists. We will argue that the United States, on the other hand, could be considered typical of the adversarial system of the Anglo-Saxon tradition. 
As background for the material that follows, Section 2 of the article presents an overview and comparison of criminal procedure in the justice systems of Switzerland and the United States. Section 3 presents the methods and results of our empirical study of how Swiss and American criminal defense lawyers deal with DNA evidence. Section 4 will discuss various possible explanations for the striking differences we observed between the Swiss and American lawyers. Section 5 acknowledges limitations, draws conclusions and discusses broader implications of our findings.

\section{Overview of the Swiss and U.S. justice systems}

A number of commentators have described differences between the adversarial systems of justice found in countries that trace their legal heritage to England and the non-adversarial systems found in most of Europe and Latin America (notably Damaška, 1995, 1997). In the Unites States, like most AngloAmerican countries, the criminal trial is a contest performed at a particular point in time between two adversaries: the government, represented by a prosecutor; and the accused, represented by a defense attorney. These adversaries conduct separate investigations and decide what evidence to offer at trial. The decision to convict or acquit rests with a lay jury, which is instructed to decide the case based only on the evidence presented during the trial. The judge rarely plays a role in investigating the case or presenting the evidence, but serves as a referee to assure the fairness of the adversarial contest. The judge controls the parties' presentation of evidence according to an elaborate set of rules designed to prevent the lay jurors from being influenced by irrelevancies or prejudice and to protect the constitutional rights of the accused. Testimony is elicited in a question and answer format so that parties may raise objections to questions that might lead to inadmissible responses. By ruling on these objections, the judge controls the flow of information to the jury. After the evidence is presented, the judge informs the jurors of the legal rules they must apply when deciding the verdict. The jurors announce their verdict to the court, but are usually not expected to explain or justify their decision.

In Switzerland, like most European and Latin American countries, criminal prosecutions are less like an adversarial contest and more like a collaborative research project. It is the investigation rather than the trial that is the centerpiece of the Swiss criminal justice system. Trials merely serve to confirm and make public the results of the investigation. Swiss criminal investigations are directed 
from an early stage by an examining magistrate, ${ }^{3}$ who gathers all relevant evidence in a common file known as a dossier. ${ }^{4}$ Once she considers her investigation to be complete, the examining magistrate refers the case to a court, where it will be heard by a single judge or, if the matter is serious, a panel of judges. In court, the judge will assess the probative value of the evidence with the help of the prosecutor, ${ }^{5}$ the defendant and their attorney, and the complainant and their representative. If necessary, he will direct that additional evidence be gathered.

Swiss trials are typically much shorter than American trials. A murder case in which the accused contests guilt will often be heard in a week. The speed of Swiss trials arises from several factors. The key actors all know the case. Because they have all had (and read) the dossier beforehand, little time is needed to establish background or contextual facts. The participants in the proceedings are rarely surprised by what the witnesses say in court: the witnesses typically are asked to confirm their previous statements, to elaborate on details that may not have been clear, and to explain any contradictions or inconsistencies. When witnesses testify, they are encouraged to speak freely in narrative fashion without the elaborate ritual of question and answer that is necessary in American courts. Questions are asked by the presiding judge - if the prosecutor or defense lawyer wishes to pose a question to the witness, they must seek the judge's permission to do so. If permission is granted, the attorney is expected to show

3 Although the examining magistrate is called a "prosecutor" in Swiss law (article 16 al. 2 of the Swiss code of criminal proceedings - hereafter CPP), this official is expected to play a neutral and objective role during the investigation. The prosecutor can convict the accused herself if the sentence is no longer than six months imprisonment, 720 hours community service, nor higher than 180 daily penalty units (article $352 \mathrm{CPP}$ ). If the expected sentence is higher, the accused must be referred to a court, which will then hold a hearing. At this stage, the prosecutor can also offer a plea bargain to the accused, if the envisaged sentence does not exceed 5 years imprisonment (article $358 \mathrm{CPP}$ ). An English version of the Swiss code of criminal proceedings is available at www.admin.ch/opc/en/classified-compilation/20052319/index.html.

4 The dossier is a physical binder, which always remains in the possession of the examining magistrate and to which all parties have access. All communications between the magistrate, the parties, the witnesses and the experts must be done or recorded in the written form, to ensure that everyone is informed of everything. That dossier is later transferred to the court. See article 100 CPP.

5 At this stage the prosecutor is an advocate for conviction. The same person can (and often does) serve as prosecutor during the investigative stage (where she is expected to take a neutral role) and during the trial (where she becomes an advocate). This dual role has been criticized as creating a risk of role-induced bias (Riklin, 1998; Wicki, 2011). 
restraint and avoid grandstanding. ${ }^{6}$ There are virtually no rules of evidence ${ }^{7}$; judges are trusted to ignore irrelevancies and avoid prejudice without having the evidence screened for them.

In both countries, the accused is presumed innocent and his guilt must therefore be proven. In the U.S., the burden befalls the prosecution. Swiss law on the other hand allots the task to all authorities: the examining magistrate and later the court have an investigative responsibility of their own, and will be very active in fulfilling their duty (article 6 CPP). Swiss law provides that the accused can be convicted only if the court reaches a "firm belief" ("intime conviction") that he is guilty. Article 10 al. 3 CPP states: "Where there is insurmountable doubt as to whether the factual requirements of alleged offense have been fulfilled, the court shall proceed on the assumption that the circumstances more favourable to the accused occurred". No unique definition of "insurmountable doubt" exists in Swiss law, but it is not uncommon for Swiss legal scholars to refer to the notion of "reasonable doubt" (Burnand, 2004; Jositsch, 2013; Oberholzer, 2012).

When Swiss judges (or judge) determine that an adequate record exists to support a decision, they issue an opinion which states their verdict and discusses in detail the reasoning underlying the decision. The verdict and the sentence are rendered simultaneously. After the decision has been rendered orally, the court will also issue a written judgment explaining what factual conclusions were reached on the basis of what evidence, how the law was applied to those facts, and how these elements justify the sentence imposed.

After the verdict is decided, the parties have the opportunity to file an appeal (article $398 \mathrm{CPP}){ }^{8}$

\subsection{Role of defense lawyer and defendant}

The collaborative ethos of the Swiss courts is seen in the way that the lawyers view their role in the system. A Swiss defense attorney ${ }^{9}$ sees herself, first and

\footnotetext{
6 The fact that attorneys play a secondary role is also apparent in their behavior: they remain at their table throughout the hearings and are not allowed to move around in the courtroom.

7 One important exception is the body of rules set out in articles 139 to $141 \mathrm{CPP}$, which prohibit the use of coercive methods of proof and limit the use of illegally obtained evidence.

8 Switzerland has three levels of jurisdictions: first instance at the local (district) level, second instance at the supreme court of the canton in which the first decision was rendered, and then at the Swiss Supreme court. If the decision of the Swiss Supreme court violates the European Convention on Human Rights, an appeal can be filed to the European Court of Human Rights in Strasbourg (France).

9 In Switzerland, one becomes an attorney after 5 years of formal legal training at a university, which one starts right after secondary school. After that, between one and two years are spent
} 
foremost, as an ancillary of justice: she considers that her role is to help the examining magistrate and the court establish the facts of the case, even if her client is guilty. ${ }^{10}$ Few attorneys ever advise their client to remain silent, even though the right to remain silent and not to cooperate with the authorities is guaranteed (article 113 al. 1 CPP). ${ }^{11}$ In fact, many attorneys consider that their clients will be better served, in the long run, if they recognize their guilt and receive adequate punishment or undergo a rehabilitation program, ${ }^{12}$ than by denying any implication in the actions for which they are prosecuted. Besides, remaining silent may well be viewed unfavorably by the judges. In practice, almost all Swiss defendants make a declaration at some point in their trial. The presiding judge typically solicits the defendant's active participation throughout the trial by encouraging him to react to the witnesses' testimony and to comment on the evidence.

It is rare for a Swiss defense lawyer to be accused of inefficiency or ineffectiveness; ${ }^{13}$ the limited nature of the defense lawyer's role makes it difficult to

as an apprentice under practicing attorneys or in a court (or both), before taking the bar exam. Most attorneys work in small practices consisting of a few associates and collaborators. Few Swiss attorneys specialize in criminal law, and most of them do not exclusively work in the field of criminal law. Switzerland does not have any public defenders' office. All defense attorneys who are registered at the bar will be called to assist indigent defendants in turns, and be compensated by the state at a fixed rate.

10 See for instance Council of Bars and Law Societies of Europe, Charte des principes essentiels de l'avocat européen at 5: "An attorney must never consciously give the court an erroneous or misleading information. This often conflicts with the immediate interests of the client but an attorney must be able to resolve such a conflict." Such a rule is justified by the fact that an attorney can only successfully represent his client if everybody can trust him. This overriding duty to justice is also illustrated in civil cases by the fact that a Swiss lawyer cannot be compensated proportionately to the outcome of a case; his fees must be independent of whether his client wins or loses. In a case from 1980, the Swiss Supreme court reminded attorneys that they must remain morally detached from their clients, keep their distance from the client's interests, and not simply be the client's spokesperson (ATF 106 Ia 100, cons. 6b, JdT 1982 I 579). If the attorney knows that the client is lying, he can nonetheless present his version of events to the court, but must do so in a restrained manner (Bohnet \& Martenet, 2009).

11 This is in sharp contrast with the comment made by Justice Robert Jackson: "Any attorney worth his salt will tell his client to refuse to answer any question from the police." (Pizzi, 2000, p. 54).

12 This, of course, must be considered in light of the relative leniency of sentences meted out by Swiss courts when compared to the United States. It is even truer in the context of juvenile delinquency, where it is considered irresponsible for a defense attorney to try to get her client acquitted if he is guilty, because it will only endanger the future of the minor.

13 For a case in Zurich in 2007, see "Zwillingsmord wird neu beurteilt", Tages Anzeiger, 06.06.2012. 
argue that the outcome of the case turned on the defense lawyer's performance. ${ }^{14}$

\subsection{Access to investigative files}

One important difference between the Swiss and American systems concerns the parties' access to investigative records. As already mentioned, in Switzerland all evidence is collected into an official dossier to which all parties to any subsequent proceedings have access. Swiss investigators operate under rules that require them to gather all evidence relevant to establishing the truth, whether it is incriminating or exculpatory for a particular suspect.

Swiss lawyers are not entitled to mount an independent investigation on behalf of a client, with the exception of consulting a private expert. They are expected to rely upon the official investigation and view their role as ensuring that the court and examining magistrate pursue all potentially helpful lines of enquiry. ${ }^{15}$ While American defense lawyers sometimes manage to surprise prosecutors with important revelations, these "Perry Mason moments" virtually never occur in Swiss courts. Swiss defense attorneys tend to share any information they intend to use as early as possible due to an ethos of sharing and collaboration. A lawyer who made surprise revelations at trial would be viewed as a grandstander who had undermined rather than supported the collaborative process of truth-seeking.

\subsection{Expert evidence}

In Switzerland, experts are usually independent scientists commissioned by the examining magistrate or the court. ${ }^{16}$ An exception to this general rule occurs for some forensic science disciplines (e. g., fingerprint identification; shoe print

14 It is difficult to fault the defense lawyer for failing to uncover exculpatory evidence, or failing to adequately challenge incriminating evidence, in a system where the defense has no responsibility for conducting an independent investigation.

15 The examining magistrate can refuse to do such investigations, in which case the defense can immediately appeal to a higher court and have the matter settled before the case is sent to court (article 393 CPP).

16 Many scholars have commented on the divergent roles and status of experts in adversarial and non-adversarial criminal justice systems (Broeders, 2003; Champod \& Vuille, 2011b; Havard, 1992; Margot, 1998; Meintjes-van der Walt, 2001; Redmayne, 2001; Saks, 2003; Spencer, 1992; van Kampen, 1998, 2003). 
comparison), where police officers with specialized training serve as experts. ${ }^{17}$ Parties generally have the opportunity to comment on the choice of an expert and to suggest somebody else. ${ }^{18}$ Parties also have the opportunity to comment on the questions put to the expert. The investigating magistrate generally prepares a charge to the expert in advance so that the parties can make suggestions or request changes.

When the expert has completed her work, she is required to file a written report (article 187 al. $1 \mathrm{CPP}$ ). ${ }^{19}$ The parties then receive a copy of the expert report and can ask further questions. If they are dissatisfied with the quality of the work carried out by the expert, they can ask that a second expert be commissioned by the investigating magistrate, either to do the analysis again or to evaluate the report drawn by the first expert. ${ }^{20}$ Legally, nothing prevents criminal defendants from hiring their own experts, instructing them as they wish, and then presenting the reports to the examining magistrate for inclusion in the official case file. But this option is rarely exercised, in part because judges tend to give less weight to the conclusions of a private expert instructed and paid by one of the parties. There is also a financial deterrent. Defendants may petition the court for reimbursement of fees paid to a private expert, but judges will do so only if they deem the report of the private expert helpful. In either case the defendant must pay the expert fee in advance, which makes it difficult for defendants with limited resources to exercise this option.

In Switzerland, all forensic DNA testing is performed by one of seven state laboratories accredited by the Department of Justice and Police. Six of them are part of state university hospitals; none of them belongs to a police force or a district attorney's office. Evidence from crime scenes is typically collected by a forensic team of the judicial police. The police have the authority to order some types of DNA testing without involvement of lawyers or judicial authorities (article 255 CPP). The investigating magistrate may also request DNA testing and may do

17 However, not all forensic practitioners serve as experts in the formal sense. Their status depends on how they were commissioned. This sometimes creates uncertainty as to their exact duties and rights in a given case (Champod \& Vuille, 2011a).

18 As discussed below, the procedure differs for experts on DNA testing and certain other specialties that are considered "objective."

19 The law also allows the examining magistrate or the court to require from the expert that she appear in court to give an oral testimony (article 187 al. 2 CPP), but this possibility, which offers the opportunity for explanation of sometimes complex matters and clarification, is seldom used. 20 It can be challenging for lawyers to establish that the services of a second expert are needed, however, without having the services of a second expert. 
so without consulting the defense lawyer. ${ }^{21}$ Once the evidence has been analyzed, the laboratory will send its report to the examining magistrate and to the police, who will interpret the results and include them in their narrative of the case. This also happens without involvement by the defense lawyer. ${ }^{22}$

In Switzerland, there are no admissibility standards such as the Frye ${ }^{23}$ or Daubert $^{24}$ criteria in the United States. According to article 139 al. 1 CPP,

21 As noted above, the traditional Swiss practice has been to allow all parties to comment on the choice of an expert and the questions put to the expert, but statutory exceptions have been made for DNA and a few other types of evidence, e. g., blood alcohol evidence (article 184 al. 3 CPP). For these types of evidence, the parties can intervene only after the expert has been chosen and the questions have been asked. These exceptions appear to reflect a presumption by the legislator that such analyses are straightforward, unlikely to be controversial, and unlikely to produce expert disagreement. Some authors have argued that this rule is misguided (Vuille \& Taroni, 2011).

22 In the United States, by contrast, DNA testing is typically performed by crime laboratories operated by law enforcement agencies. Occasionally a police agency will hire a privately operated forensic laboratory to perform DNA testing. Private labs are used when the police agency does not have access to a government crime laboratory or where the agency is requesting a type of testing that the government laboratory cannot provide. In most jurisdictions, crime laboratories are operated by police departments; in a minority of jurisdictions the crime labs are operated by district attorney's offices. Crime laboratory personnel often help collect samples at crime scenes. Samples may also be submitted by police officers, hospital sexual assault teams (who collect samples from victims of sexual assaults) and medical examiners (who collect samples from homicide victims). Decisions about which samples to test are typically made by police investigators and crime laboratory personnel, sometimes in consultation with deputy district attorneys. Defense lawyers are never involved in these decisions even if a defendant has already been charged. Defense lawyers typically learn about DNA evidence when the district attorney discloses a laboratory report. At that point, defense lawyers may ask for additional documentation of the scientific testing. If the prosecutor refuses to disclose the records requested, the defense lawyer must file a motion for discovery with the court. Courts generally grant requests for records that relate directly to the evidence that the government will present at trial, such as chain-of-custody records and laboratory notes. Courts vary greatly in their willingness to grant broader requests, such as requests for results of any research the laboratory has done to validate its methods, results of proficiency testing, records of errors or problems that have occurred in other cases, and records of previous errors or misconduct by laboratory personnel (Thompson, 2006).

23 The standard for admissibility of expert evidence first articulated in Frye v. United States, 293 F. 1013 (D.C.Cir.1923) requires courts to determine that proffered testimony is based on a theory or method that has "general acceptance in the particular field to which it belongs."

24 In Daubert et al. v Merrell Dow Pharmaceuticals Inc., 509 US 579 (1993) the Supreme Court provided guidance to federal judges on how to apply Federal Rule of Evidence 702, which concerns the admissibility of expert evidence. The "Daubert standard" requires the trial judge to act as gatekeeper to "ensure that any and all scientific testimony or evidence admitted is not only relevant, but reliable.” Id. at 589. 
scientific evidence will be considered if it is apt at establishing the truth, i. e. if it is reliable, but the law does not specify how judges should assess reliability. In practice, the only types of scientific evidence that are excluded are those arising from obvious charlatanism. Judges are trusted to give other types of expert evidence the weight it deserves (Champod \& Vuille, 2011b).

\subsection{What Swiss judges understand about DNA evidence}

In a research project conducted in 2009-2011, the first author sought to identify what Swiss judges knew about DNA, what they thought of it, and how they saw their role with regards to it in criminal cases (Vuille, 2011, 2013). The goal of that project was to evaluate whether certain problems that had been identified in the (mainly English-language) literature about juries' misunderstanding of DNA evidence are avoided when professional judges evaluate the reliability and probative weight of DNA evidence. Interviews were conducted with judges, lawyers and DNA experts who were active in Swiss courts.

It appeared that Swiss judges had limited knowledge of DNA evidence. What came as a surprise, though, was that, for various reasons, they did not consider it their role to scrutinize DNA evidence, because they expected the defense attorneys to complain about the evidence if they were dissatisfied with it. Prosecutors, who often rely heavily on DNA evidence to establish guilt, were not inclined to question it. ${ }^{25}$ And defense attorneys reported not reviewing it either, saying that the law prescribed that this was the duty of the judge (which is correct). In the end, it appeared that nobody reviewed the DNA evidence carefully. There was a strong expectation, by judges and prosecutors, that the defense attorneys would take matters in their hands if they felt that there might have been a mistake made in the process. But the defense lawyers seemed to feel no special responsibility to do so. ${ }^{26}$

Based on this result, we decided to expand the project, focusing specifically on defense attorneys and increasing our sample to include more Swiss defense lawyers and a comparison sample of American defense lawyers. We wanted to learn more about what defense lawyers know (or think they know) about DNA

25 This supports the idea, expressed by some American scholars and lawyers, that the nonadversarial system lacks incentives for neutral magistrates to probe deeply enough into the facts (van Kessel, 1991).

26 Part of the problem might be that defense lawyers have been conditioned to expect that the judge would take the primary role in examining DNA evidence, since judges do so for other types of evidence (Vuille, 2011). Similar speculations have been made about German attorneys (Jescheck, 1970). 
evidence and how they view their own responsibilities in dealing with it. We also thought that a direct comparison between Swiss and American defense lawyers would help us understand the range of ways in which defense lawyers might engage with DNA evidence, as well as casting broader light on the operation of the two systems of justice. ${ }^{27}$

\section{How elite American and Swiss lawyers perceive and handle DNA evidence}

\subsection{Methodology}

We conducted semi-structured interviews ${ }^{28}$ with 24 attorneys, 11 in the U.S. and 13 in Switzerland. ${ }^{29}$ We identified potential interviewees by asking well-connected colleagues in the legal communities of both countries to identify leading practitioners who specialize in criminal defense and are knowledgeable about DNA evidence. We then expanded the sample through "snowballing" (i.e., asking participants to identify peers who are expert in dealing with DNA evidence). ${ }^{30}$ We sought prominent lawyers who are highly regarded by colleagues and who serve as "opinion leaders" for the field. Our interviewees had various marks of distinction, such as occupying prominent roles in bar associations, active involvement in continuing legal education and other training activities, and reputations for successful performance in difficult, high-profile cases.

27 It has been pointed out that scholarship on comparative criminal procedure tends to focus on theoretical aspects that are sometimes divorced from their applications in real cases (Lerner, 2001). Furthermore, merely reading the law is an unsatisfactory way to investigate the attitudes of legal actors in a given system and the effective roles that they play in their daily practice because local legal culture shapes the way a given legal provision is applied (Alldridge, 1999). 28 The use of semi-structured interviews is recommended to explore the attitudes of a person with regards to a given topic, to determine her opinions and mental representations on certain facts or events, to investigate how she interprets their meaning and how her understanding of the world, in turn, shapes her behavior. It allows the researcher to comprehend the phenomena under study in their complexity and variety, and favors a reflexive approach (Flick, 2009; Rubin \& Rubin, 2005). On semi-structured interviews, see also Kaufmann (2004) and Quivy and Van Campenhoudt (1995).

29 In the following quotations, American attorneys will be identified with the letter "A" and Swiss attorneys with the letter "S". Each of them will also be identified by a number. 30 On snowballing, see for instance Miles and Huberman (2003), p. 58. 
Some initial differences between the U.S. and Swiss lawyers became apparent during the sampling phase of the study. It was easy to find criminal defense lawyers in the U.S. who are known and highly regarded for their expertise regarding DNA evidence. We found no such specialists in Switzerland. Our Swiss interviewees were prominent and highly experienced lawyers who had dealt with DNA evidence in multiple cases, but none of them claimed to have specialized knowledge of DNA evidence, and none of them knew of any Swiss lawyers who were considered DNA specialists.

The main questions asked of both Swiss and American interviewees were the following:

- How do you see the role of the defense lawyer in a criminal trial, with regards to DNA evidence?

- What knowledge is needed to perform that role well?

- How did you or do you acquire that knowledge? How do you think that knowledge should be acquired?

- When do you get an expert?

- What does the expert do that helps you?

- What issues do you encounter most in DNA cases?

- If you could change anything in the way things are currently done in your jurisdiction, what would it be?

The questions were adapted to follow the flow of the narration of each interviewee, and additional topics were explored when interviewees addressed such topics. ${ }^{31}$ The interviews were audio recorded when the interviewee consented to it, then transcribed and coded in compliance with the principles set out in the literature. $^{32}$ The data were then analyzed using a grounded theory approach (Glaser \& Strauss, 2008). The authors gained additional insights by attending multiple courtroom proceedings in the two nations in which DNA evidence was presented.

31 Giving the opportunity to the interviewee to emphasize the topics that she deemed important, even if we had first considered it secondary or not considered it at all. One should note though that interviews with Swiss attorneys tended to stray from this list since many questions were considered by them to be irrelevant to their daily practice.

32 See for instance Flick, 2009; Gibbs, 2007; Kvale, 2007; Miles \& Huberman, 2003; Silverman, 2005, 2006. The interviewing, transcription and analysis were all done by the first author. The interviews conducted in Switzerland took place in French; a free translation in English of representative comments is offered here. 


\subsection{Overview of results}

We found striking and consistent differences between the Swiss and American lawyers in their views of forensic DNA evidence and how they handle it. The Swiss lawyers said that they almost never challenge DNA evidence. They view it as entirely objective and virtually infallible. They think that DNA experts are neutral, that their results and interpretations cannot be influenced by partisanship or bias, and hence that their conclusions are largely incontestable. In their view, there is little or nothing for a defense lawyer to do, with regard to DNA evidence, because the evidence speaks for itself in a clear, powerful way. By contrast, the American lawyers, while viewing DNA evidence as powerful, claimed that the interpretation of DNA tests is often subjective, that mistakes in DNA testing are possible and more common than most people realize, that statistical characterizations of tests results are often exaggerated or skewed, that DNA experts may slant their reports and testimony in a manner designed to support the perspectives of police and prosecutors, and hence that DNA evidence is often contestable. They emphasized that defense lawyers must work very hard to evaluate DNA evidence in order to understand its limitations, explore possible alternative explanations for seemingly incriminating findings, and assure that the evidence is presented fairly and accurately to the trier-of-fact.

It is important to note at the outset that we found complete unity among the Swiss lawyers, and among the American lawyers, in their attitudes and perspectives on DNA evidence. The complete consistency of the responses within our American sample, and within our Swiss sample, gave us confidence, even though our samples are small, that the differences we observed reflect true differences in the underlying populations from which we sampled - i. e., elite Swiss and American criminal defense lawyers who deal with DNA evidence. Because the Swiss lawyers all shared one perspective on DNA evidence, and the American lawyers all shared another quite different perspective, it is fair to say that there was a Swiss perspective and an American perspective on DNA evidence. The two perspectives were strikingly different.

\subsection{Is DNA evidence contestable?}

The Swiss lawyers regard DNA evidence as incontestable. They see it as definitive - not something that they can challenge:

DNA is the supreme element against which any form of argument is pointless (S10)

When there is DNA or fingerprints, there's nothing we can do (S6) 
To the Swiss lawyers, DNA evidence is completely objective. It is not subject to alternative interpretations; it cannot be biased:

DNA results cannot be contested, it's an exact science, it's chemical and mechanical measurements (S11)

For us, DNA is absolute proof (S12)

When there is DNA evidence in a case, Swiss lawyers see their role as limited because (in their view) one cannot fight results that are so absolute, objective and powerful. The only forms of uncertainty acknowledged by our Swiss interviewees relate to the chain of custody. One recalled a case in which a son was suspected of having murdered his mother and a friend of hers. DNA of the son was found on the apparent murder weapon, a pair of scissors found with the bodies in the mother's house. But evidence emerged that the scissors had been misplaced at some point during the investigation. Because the chain of custody was broken, the significance of the DNA finding was called into question. Another Swiss interviewee said that she always conducts a thorough evaluation of the DNA evidence in her cases. But when asked what she does exactly, it appeared that she merely checked the reference numbers of the samples analyzed as reported in the expert report. Asked about what errors he could imagine during a DNA analysis, another attorney explained that, in his opinion, the only possible error would be a sample switch at the laboratory. ${ }^{33}$

In fact, two groups emerged among the Swiss interviewees. One group could imagine, theoretically, that errors could occur, but considered such an event so unlikely that it did not warrant serious consideration. In the words of one of our interviewees:

Theoretically, there is always a possibility that there was a mistake in the DNA report. But it is so little realistic (S11)

Another group thought it possible that errors could occur frequently enough to be of concern, but saw nothing that a lawyer could do about it:

If there is an error in the laboratory analysis, there is no way for us to know (S2)

33 Note also that, in their representations, the laboratory was the place where things could go wrong. And yet, the evidence has a life before and after the laboratory, and mistakes can also happen at the crime scene, during transportation, or when the experts write up their reports (and make clerical errors, for instance). On the preeminence of the laboratory in the forensic discourse, see Willis (2009). 
The attitude of the American lawyers offered a stark contrast to the resigned impotence of the Swiss. While the American lawyers saw DNA evidence as formidable, they all said that there are many possible ways that it can be challenged. The American lawyers do not see DNA evidence as entirely objective. They believe even the most basic interpretation of the test results - whether a particular individual could or could not have been a contributor to a particular sample - is sometimes subject to dispute. They also questioned the correctness of statistical calculations and were quick to posit ways that an innocent person could be mistakenly incriminated:

So when I get a DNA case the first thing I look at is, can the defendant really be included as a contributor, and sometimes it is easy because there is a single source sample but a lot of times it is messy, and then as a defense attorney I say, are there other interpretations that could be made about the DNA profile and comparing it to other people than my client, what is the significance of the statistic, did the scientist use some judgment that I can make an argument about, and then I have to look of course at the underlying data, how did they process, how did the evidence come into the lab, was it contaminated. (...) Always I am questioning that conclusion that the defendant is the one, well, sometimes I'm questioning the fact that the defendant left the DNA, at other times I'm questioning what is the significance of the DNA (A2)

\subsection{The importance of close examination of DNA evidence}

A common theme among the American lawyers was the importance of examining DNA evidence carefully in order to verify the fairness and accuracy of the government's interpretation. They suggested that DNA evidence is often overstated or presented in misleading ways by experts who fail to acknowledge underlying uncertainties:

Defense attorneys have always taken scientific evidence like it was the Gospel, up until 20 years ago, but then people realized that it is not infallible, for one thing, and also that there are a lot of scientists out there doing frankly duplicitous things, and things require a lot of scrutiny (A4)

The American lawyers also emphasized the importance of gaining access to all of the underlying scientific data in order to scrutinize it carefully and, when needed, obtain expert assistance:

[My role is to] evaluate the impact of the DNA on the case, ask for enough information so that you can make a reasoned evaluation of the conclusions and if necessary consult with an expert to help you with that evaluation (A6)

My role as a defense attorney is to examine the DNA evidence in as much detail as I can, make sure that I get everything, all the data (A10) 
The American lawyers emphasized that, like any other type of evidence, DNA evidence must be examined closely. Indeed, the American lawyers said that DNA evidence warrants particularly close scrutiny because its supposedly high credibility may not always be warranted. Contrary to their Swiss colleagues, no American attorney suggested that DNA evidence is incontestable, or that attempting to challenge it is pointless. They believe that DNA test results that initially appear incriminating can sometimes have other interpretations and that defense lawyers, through careful analysis, may find alternative interpretations that are consistent with a theory of innocence or of lesser culpability than was initially apparent. They emphasized that every element of DNA testing needs to be checked, because a) an honest mistake is always possible and b) there are no guarantees that all people involved in the process are unbiased and honest. Even the presentation of results can be biased. Hence, the defense attorney must also take care to assure that incriminating results are not overstated.

I'm not sure it's either incompetence or dishonesty on the part of the lab when they choose one interpretation that suits their case. They choose the interpretation that they think is scientifically justified and they come in and defend it. And my job is to show that it's not the only interpretation, and to get them to admit that there are other interpretations. If they are doing their job properly, they will admit that there are other interpretations but explain why they think that their position is justified (A10)

The attitude of the Swiss lawyers could not have been more different. Because they viewed DNA evidence as incontestable, the Swiss lawyers saw little point in inquiring into the details of DNA testing and made little effort to do so. They rarely looked beyond the laboratory report. They rarely sought an independent scientific evaluation of the laboratory work. They simply accepted the conclusions of the expert report as given and did not try to challenge it. Indeed, they suggested that close examination of DNA evidence is pointless because it is uniquely invulnerable to challenge.

With other types of evidence, for instance a witness testimony, the judge has free range to evaluate the evidence and that's when the defense attorney comes in, presenting the suspect's position, even if the judge is then free to decide what he makes of it. But with DNA, whatever the defense attorney says, it doesn't make a difference. All he can do is try to mitigate the sentence. I'm overstating it of course (S9)

This attitude of hopeless resignation did not extend to other forms of expert evidence. When psychiatric or psychological conclusions are offered in evidence, Swiss defense attorneys are much more critical and scrutinize the evidence in a way that is similar to what our American interviewees say they do 
when confronted with DNA evidence. For example, provided the report is unfavorable to their client, Swiss attorneys report that they spend many hours trying to understand the report, identifying weaknesses, researching conflicting literature on the internet, and finally hiring another psychiatrist to have the first report evaluated, and possibly write a second report concluding differently. When asked why they give less scrutiny to DNA evidence, the Swiss lawyers suggested that psychiatry and psychology are imprecise disciplines, where multiple interpretations are possible, while DNA test results are clear cut and absolute. Furthermore, because psychiatry, like the law, has human motives and behavior as a central object, they believe that they, as lawyers, have a basis for judging psychiatric conclusions (Vuille, 2011).

It is noteworthy that the American attorneys displayed a much broader knowledge of DNA than our Swiss respondents. The Americans spontaneously initiated technical discussions with the interviewer on nuances of DNA testing, such as population statistics, interpretation of mixed DNA samples, statistical characterization of mixed or incomplete DNA profiles, and problems of typing low quantities of DNA. This is not surprising in itself, since our American interviewees were chosen specifically because they were DNA specialists. Because our Swiss respondents were generalists who claimed no special expertise in DNA evidence, we expected them to be somewhat less knowledgeable. But the gap in understanding was much greater than we anticipated. The Swiss lawyers seemed to know little more about DNA evidence than an average citizen would. For example, when asked about mistakes that might occur in DNA testing, Swiss attorneys had little to say; they could think of only a few obvious possibilities, such as a sample switch at the laboratory, or the possibility that a suspect might have an identical twin. The American attorneys, by contrast, went on at length about ways in which false or misleading results might arise from errors in collection or handling of samples, errors in processing of samples in the laboratory, misinterpretation of test results, incomplete reporting of test results, mischaracterization of the statistical value of test results, errors in reporting, and bias in expert testimony. The American lawyers were comfortable speaking in technical language about the potential for and implications of crosscontamination, "stutter," "allelic drop-out," "stochastic effects," probabilities of exclusion, likelihood ratios and the like. The Swiss lawyers were unfamiliar with this terminology, apparently had no knowledge of the underlying technical issues, and many of them showed little interest in either.

I don't think there would be an added value if defense attorneys got educated in DNA, DNA is one of the only cases in which science gives justice objective and undisputable evidence, that's rare, usually people present multiple versions of the same event, the judge is free to 
find one way or the other, rarely is there an established truth, justice is human and sometimes there are wrongful convictions, the district court says something, the appeal's court says something else and at the supreme court something different still, but this is not the case with DNA, I don't see why attorneys should get an education in the field of DNA (S9)

\section{Explaining the difference}

What does this striking and consistent difference in the perspective of defense lawyers tell us about the Swiss and American legal systems? Does it offer lessons about the relative advantages of adversarial and non-adversarial legal systems, or about the general character of such systems? To address these questions we must consider underlying reasons for the observed differences. Knowing why these differences arose is the first step in assessing their broader significance. Inevitably we must ask which perspective on DNA evidence corresponds more closely with ground truth. If DNA evidence is as problematic as the American lawyers claim, then the Swiss lawyers are woefully deficient in defending the interests of their clients. If DNA evidence is as trustworthy as the Swiss believe, then the American lawyers are wasting an extraordinary amount of time and effort pursuing bogus issues. These alternative explanations have vastly different implications for an assessment of the underlying legal systems. Hence, we must first consider which perspective on DNA evidence better corresponds with the truth. We must also consider whether the "truth" about DNA evidence varies between the two jurisdictions - i.e., whether the DNA evidence presented in Swiss courts is more trustworthy than the DNA evidence presented in American courts, such that the divergent perspectives of the American and Swiss lawyers could both be correct.

\subsection{Adversarial excess: Are American lawyers raising bogus objections?}

Forensic DNA testing is widely perceived as a powerful and reliable method of human identification. It has been used successfully both to prove the guilt of accused suspects (Kaye, 2010) and to exonerate people who were mistakenly convicted based on other evidence. DNA evidence has been called the gold standard of forensic science, a "truth machine" (Lynch, Cole, McNally, \& Jordan, 2008). So it is important to consider whether the strenuous efforts of American defense attorneys to challenge DNA evidence are a misguided effort to 
contest the incontestable and hence an example of adversarial excess that harms rather than supports the cause of justice.

We began our analysis of the issue by asking whether the perspective of the American lawyers is supported by the scientific literature on forensic DNA testing. In virtually every instance we found that the statements of the American lawyers about potential problems with DNA evidence have ample scientific support. While there is no doubt that DNA testing has the potential to produce extraordinarily powerful and convincing evidence, that extraordinary potential is not always realized. In practice the strength and quality of DNA evidence can vary dramatically from case to case. Although promoters have claimed from the beginning that DNA tests are virtually infallible (Aronson, 2007), surprising numbers of cases have come to light in which DNA evidence implicated the wrong person (Gill, 2014; Murphy, 2015; Thompson, 2006, 2012).

For example, there is a growing scientific literature that supports the claim of the American defense lawyers that DNA can inadvertently be transferred from one item to another item, both outside the laboratory and inside the laboratory, creating a potential for false DNA matches (Daly, Murphy, \& McDermott, 2012; Fonnelop, Egeland, \& Gil, 2015; Goray \& van Oorschot, 2015; Poy \& van Oorshot, 2006; Zoppis et al., 2014). False incriminations from this process have been documented in a number of instances (Murphy, 2015; Thompson, 2012). So we find it entirely appropriate that defense lawyers investigate and consider whether cross-contamination or accidental DNA transfer could have produced an incriminating result in their cases, and to raise that possibility in court when it cannot be ruled out. Where the presence of DNA on an item purportedly collected at a crime scene is what incriminates the defendant, we think a competent defense lawyer must examine the manner in which various samples were collected and processed to assess whether a sample known to contain the defendant's DNA (e. g., a reference sample or a sample from another location where the defendant had a legitimate reason to be) was in close proximity to the crime scene sample under conditions where cross-contamination could have occurred. To conduct such an examination, the defense lawyer must look beyond the laboratory report to the underlying notes and records regarding collection and processing of the samples. The lawyer might also need to consult with an expert about the plausibility of various theories of how DNA in the quantity detected in the crime scene sample could have gotten into that sample accidentally. This is exactly the type of analysis that the American defense lawyers described as an essential part of their work; it is a type of analysis that none of the Swiss lawyers considered necessary and none had ever performed.

The scientific literature also supports the claim of the American defense lawyers that DNA test results are sometimes subject to multiple interpretations 
and that experts often rely on subjective judgment to determine which of several possible interpretations to adopt (Gill, 2014; Thompson, 2012). Under ideal conditions, the results of forensic DNA tests are clear-cut and easy to interpret. But conditions are not always ideal. When labs try to "type" samples that contain too little DNA, or DNA that is too degraded, the results can be unreliable (Butler, 2010; Gill, 2014; Murphy, 2015; Thompson, 2009). The test may fail to detect certain genetic characteristics of people who contributed DNA to the sample; the tests may falsely detect characteristics that did not come from contributors; and the test results may be distorted in other ways that complicate interpretation. Under these circumstances, the experts' interpretations become more subjective and expert opinions may differ (Dror \& Hampikian, 2011; Thompson, 2009).

The potential subjectivity of forensic DNA analysis was highlighted in a recent report by the President's Counsel of Advisors on Science and Technology (PCAST, 2016), which discussed the foundational validity of a number of forensic science disciplines. It concluded that valid and reliable methods exist for analysis of "single-source samples and simple mixtures," although it noted that these methods are "not infallible in practice" (PCAST, 2016, p. 73). ${ }^{34}$ But it reached a different conclusion regarding the analysis of more complex samples:

DNA analysis of complex mixtures - defined as mixtures with more than two contributors is inherently difficult and even more for small amounts of DNA... [Hence], it is often impossible to tell with certainty which alleles are present in the mixture or how many separate individuals contributed to the mixture, let alone accurately to infer the DNA profile of each individual (PCAST, 2016, p. 75-76).

It went on to conclude that the approach taken by most forensic laboratories to interpreting complex mixtures is "problematic because subjective choices made by examiners, such as about which alleles to include in the calculation, can dramatically alter the result and lead to inaccurate answers” (PCAST, 2016, p. 76)

A dramatic illustration of the potential for subjectivity and error in forensic DNA analysis was reported by Dror and Hampikian (2011), who asked seventeen qualified DNA analysts from accredited laboratories to evaluate independently the DNA evidence that had been used to prove that a Georgia man participated in a gang rape. Twelve of the analysts said that the Georgia man should be excluded, four judged the evidence to be inconclusive, and only one agreed with the interpretation of the original analyst that had caused the Georgia man to be convicted and sent to prison. In another study 19 DNA experts from multiple

34 The report noted that errors "can and do occur in DNA testing" due to factors such as "sample mix-ups, contamination, incorrect interpretation, and errors in reporting” (p. 73). 
jurisdictions (including European forensic institutes) were asked to analyze the same case. Their conclusions varied wildly, with one excluding the suspect, one including the suspect with a low random match probability, and others calling the comparison inconclusive (de Keijser, Maisch, Luining, Kranenbarg, \& Lenssen, 2016).

In light of such findings, we think it entirely appropriate that defense lawyers investigate and consider whether the DNA evidence that incriminates their clients could have been influenced by subjectivity and bias. Indeed, as with the issue of cross-contamination, we think it is irresponsible for a defense lawyer to ignore or dismiss this issue without investigating it.

The scientific literature also supports the claim of the American defense lawyers that the statistics used to characterize the strength of forensic DNA evidence are sometimes inappropriate and misleading (Butler, 2010; Gill, 2014; Murphy, 2015; PCAST, 2016; Thompson, 2009; Thompson, Mueller, \& Krane, 2012). When dealing with mixed samples (containing DNA of more than one contributor) many laboratories report statistics on the "combined probability of inclusion" (CPI), which is an estimate of the probability that a random unrelated person would be included as a possible contributor to the DNA mixture. Yet the PCAST report declared that this method is "problematic because subjective choices made by examiners ... can dramatically alter the results and lead to inaccurate answers" (p.76). It concluded that "interpretation of complex DNA mixtures with the CPI statistic has been an inadequately specified - and thus inappropriately subjective - method." (p. 78). It noted that minor changes in the way that laboratories compute the CPI have produced "large shifts" in the statistics that are reported for the same case. (p. 78).

The scientific literature also reveals a variety of other statistical issues that criminal defense lawyers may need to consider when assessing the value of DNA evidence. For example, it appears that there is often distortion of DNA profiles and loss of data when laboratories type samples with extremely low quantities of DNA. Although these phenomena need to be taken into account when computing statistics on the chances of a coincidental match, experts often disagree about the best way to do so, and these disagreements can result in widely different statistics being reported on the same data (Butler, 2010; Gill, 2014; Murphy, 2015; Thompson, 2009; Thompson, Mueller, \& Krane, 2012). Additionally, because the probability of a coincidental match is higher for relatives than for unrelated individuals, lawyers may need to consider whether the possible donors of a given sample might be related, and if so whether appropriate statistics have been computed in light of that relationship (Butler, 2010). Lawyers may also need to give careful consideration to the manner in which a suspect is identified. The chances that the DNA match arose through 
coincidence may be much higher when the match was a "cold hit" from a database than when the match arose from testing a single individual who was already a suspect (Song, Patil, Murphy, \& Slatkin, 2009).

The American lawyers we interviewed were aware of most of these statistical issues and reportedly made assiduous efforts to determine the ways in which these issues might affect the evidence in their cases. The Swiss lawyers were largely unaware of these issues and seemed to accept uncritically whatever statistics the laboratory provided. The American lawyers were deeply engaged in the nuances of statistical debates over mixture interpretations, the statistical implications of "cold hits" and other such matters; the Swiss lawyers were oblivious to these issues.

In light of these observations, it is difficult to argue that American attorneys merely raise bogus objections to DNA evidence. Our interviewees reported multiple instances in which the examination that they carried out or the objections that they raised were fruitful. Some of our interviewees had raised successful challenges to the admissibility of DNA evidence in particular cases under the Daubert or Frye standard. Some reported that defense challenges to DNA evidence had led to improvements in laboratory practices. ${ }^{35}$ Moreover, the American lawyers reported a number of instances in which their careful reviews of DNA evidence had uncovered seemingly significant issues, such as unreported deviations from laboratory protocols, bad laboratory practices, ${ }^{36}$ evidence of problematic, biased interpretation, ${ }^{37}$ reliance on unwarranted assumptions, ${ }^{38}$ inconsistent practices across cases, ${ }^{39}$ and failure to document errors or problems in analyses. The defense lawyers reported that their investigation of DNA evidence frequently yielded information that they could use in cross-examination to force prosecution experts to moderate their conclusions, acknowledge uncertainties, and admit possible shortcomings. The American defense lawyers also said that their investigations alerted them to circumstances

35 One attorney said he had filed a formal complaint with the Department of Justice concerning the statistical procedures used by a federal laboratory; a review by independent experts confirmed the alleged problem and led to a change in procedure.

36 Such as not changing gloves after re-arranging items to be photographed.

37 Like looking at the reference profile while interpreting a complex mixture, or changing the RFU threshold to "adapt" the results to the reference profile of the defendant.

38 For example, the assumption that there are two contributors to a mixture, or that the accused is included in the match when in fact some of his alleles are missing.

39 For instance, including the accused as a contributor to a mixture in spite of missing alleles, while excluding another possible source precisely because of missing alleles. Or interpreting a mixture based on the assumption that it did not contain the victim's DNA when the knife was actually retrieved from the victim's chest. 
in which challenging DNA evidence was unlikely to be fruitful because the test results were solid, convincing, and correctly reported. In those instances they focused on other lines of defense or sought to resolve the case through a negotiated plea. They claimed that knowing when to challenge DNA evidence and when to accept it was one of the primary benefits of closely examining the underlying data. The Swiss lawyers, by contrast, accepted the DNA evidence in every case, without ever conducting the examination needed to determine whether that trust is justified.

\subsection{Is Swiss DNA evidence more trustworthy than U.S. DNA evidence?}

Forensic laboratories in the United States and Switzerland use the same general methods for DNA testing. Although there are some minor differences in how these methods are implemented, these differences do not preclude the kinds of problems identified by the American defense lawyers, and discussed in the scientific literature, from occurring in Switzerland.

The potential for misleading results due to cross-contamination of samples, for example, is a universal problem arising from the high sensitivity of modern DNA tests, which can detect and type tiny quantities of DNA. Swiss DNA tests are no less sensitive than U.S. DNA tests and Swiss DNA no less likely to be transferred from one item to another through physical contact. The need for subjective judgment when interpreting DNA test results is also a universal problem, arising from inherent limitations of the DNA testing technology. With the current technology, the judgment of an analyst is needed to distinguish signal from noise, to determine which characteristics of a mixed sample are associated with which contributor, to determine the number of possible contributors, to assess the possibility that the test failed to detect some characteristics of some contributors, and similar matters. These issues are no less likely to arise in Switzerland than the U.S. The difficulty of finding an appropriate statistical characterization of DNA test results is also a universal problem for DNA testing, as much a problem for Swiss as American DNA analysts. So we strongly doubt that the trust that the Swiss lawyers place in Swiss DNA evidence is fully justified.

It is certainly true that Swiss labs are well funded and closely supervised (accreditation by the Swiss Department of Justice and Police being compulsory to carry out forensic DNA testing). Hence, it is possible that Swiss police and Swiss laboratories are more careful than their U.S. counterparts in efforts to avoid cross-contamination of samples than their American counterparts. It might 
also be the case that Swiss DNA analysts are more cautious and conservative in their interpretations than U.S. analysts, and more careful when in doubt to choose the interpretation and present the statistical characterization most beneficial to the accused. But Swiss lawyers have no basis for believing those things to be true. There are no published studies of how often mistakes occur in Swiss forensic DNA laboratories. And even if the Swiss labs do use better procedures for DNA testing, it is likely merely to reduce, not to eliminate, the potential for problems. Hence, the "trust-but-don't verify" approach of the Swiss defense lawyers would still be unwarranted.

An important concern about adversarial systems of justice is that experts may be subject to adversarial pressures, making them more likely to give onesided, partisan testimony. The American defense lawyers claimed that adversarial pressures often led to distorted, unjustifiable testimony by DNA experts.

(Q: Are you saying that the problem lies more with the prosecutor than with an expert who would be biased towards the prosecution?) A: Actually it's a combination of the two, often the prosecution experts are more than happy to bend over backwards to support a theory that is not supported by the evidence, not supportable even in the larger sense, in the sense that nobody in the scientific area of what they're talking about would agree with that (A5)

The Swiss lawyers expressed much greater confidence in the neutrality of their experts.

My presumption, but it can be reversed, is that the expert is honest (S12)

Swiss lawyers offered some complaints about partisanship, particularly by police witnesses:

There is a grey area [in police reports] that is more or less intentional, reports remain fuzzy, either because [the police] don't know, or because they don't want to weaken the evidence, they don't say "we don't know", they remain silent and if you don't ask them, this piece of information is lost (S2)

And these complaints sometimes implicated the neutrality of scientific evidence:

Often the expert is merely asked to confirm that the hypothesis of the police is correct, and not to conduct their proper evaluation. So you end up with results of the type "these injuries are compatible with a homicide”, ok, but are they also compatible with something else? (S3)

But these complaints about partisanship were never extended to DNA experts. In the view of the Swiss defense lawyers, the police and prosecutors might be biased, but not DNA experts.

We question whether this faith is justified. Even in a non-adversarial system it seems possible that DNA experts might develop a pro-prosecution perspective 
after working many years in the lab and taking part in many prosecutions. Indeed, examples of non-adversarial experts exhibiting partisanship have been reported, as in the Schiedam Park murder case in the Netherlands (Brants, 2008; van Koppen, 2008). While adversarial pressures are undoubtedly less in a nonadversarial system like Switzerland than in the U.S., it seems doubtful that such pressures are entirely absent. In sum, there is no convincing evidence that Swiss DNA test results are not subject to the kinds of problems recognized by American defense lawyers and discussed in the scientific literature. ${ }^{40}$

So we are compelled to conclude that the elite Swiss defense lawyers that we interviewed were not doing as good a job as their American counterparts in representing the interests of their clients in cases involving DNA evidence. The American lawyers made a careful assessment of the DNA evidence offered against their clients and, in some instances, identified important problems or uncertainties that could be raised at trial. The Swiss lawyers simply accepted that the DNA evidence offered against their clients was sound, without looking beyond the conclusions in the laboratory report. They did not do an adequate job examining the evidence. They may well have missed significant issues that would have benefitted their clients if known.

In the sections that follow, we will consider various possible explanations for the superior performance of the elite American defense lawyers, relative to elite Swiss lawyers.

\subsection{Size and specialization}

One possible explanation for the difference between the U.S. and Switzerland relates to the relative size of the two countries. With over 300 million inhabitants, the United States is a far larger country than Switzerland, which has 8 million inhabitants. Because there are many more criminal defense lawyers in the United States than Switzerland, there may be greater opportunities for specialization, making it more likely that a group of lawyers would emerge in

40 In fact, since the interviews were conducted, at least two separate Swiss cases have surfaced in which DNA evidence led to the wrongful conviction of the accused, apparently because of sample switches. Tribunal cantonal du Jura, jugement du 21 janvier 2015, CP40/2014; Tribunal cantonal de Neuchâtel, jugement du 31 juillet 2014 (CPEN.2014.16). In another recent case, a man was convicted of arson on the basis of DNA found at the crime scene. It later became clear that he had an air-tight alibi and he was acquitted on appeal; it is not clear how his DNA found its way on the crime scene, but such cases demonstrate that, in Switzerland too, it is worth scrutinizing the meaning of DNA evidence in a given case ("Prévenu libéré malgré son ADN sur les lieux du crime”, 20 Minutes, August 21, 2016). 
the U.S. who specializes in defending clients implicated by DNA evidence. Under this theory, the existence of the differences between the U.S. and Switzerland reported here tell us little about the character of the legal systems per se, but are simply a function of the general association of larger professional populations with greater diversity of professional function. In other words, the apparent American advantage arises simply from the size of the country rather than from any distinct features of its legal culture.

While we give some weight to this theory, we doubt it is the best explanation. We found defense DNA specialists in a number of U.S. jurisdictions. While there was some coordination and sharing of information among these specialists, most of them claimed to have developed an interest in DNA evidence on their own and to have developed expertise largely through self-study. Even smaller U.S. jurisdictions, with populations lower than Switzerland, appear to have developed certain lawyers who are the "go to" expert on defending clients incriminated with DNA evidence. So it seems unlikely that Switzerland would have not even one DNA specialist if population size were the sole issue.

Based on our interviews we suspect the real problem in Switzerland is not a lack of lawyers who might specialize in this area, but a lack of interest among the defense bar in doing so. The Swiss lawyers see no point to studying DNA evidence. Because they trust it and accept it as essentially infallible, they see no advantage to knowing more about it and prefer to invest their time elsewhere. There is also, we think, reluctance among the Swiss lawyers to challenge accepted truths that may reflect an important element of Swiss legal culture.

\subsection{Legal culture}

\subsubsection{Consensualism versus antagonism}

It emerged from the data that, compared to the general atmosphere in the American criminal justice process, a Swiss prosecution and trial is a very consensual event. Judges, prosecutors and defense attorneys all see themselves as being a part of the same institution, and working together to uncover the truth. In the words of one of the Swiss interviewees:

DNA is a step forward for criminal justice, a defense attorney does not want to set criminals free, making the criminal justice system work is a concern for all attorneys (S9)

Consensualism is probably caused (or at least reinforced) by the fact that Switzerland is a small and homogenous country, with a judiciary that is a 
small community composed of people who have known each other for a long time and have collaborated on various cases. ${ }^{41}$

In the criminal justice system [of our canton], there is a very parochial state of mind, you respect the pastor, the school teacher and the mayor, they all have a special aura, you believe what they say (S7)

In this context, "acting out" is frowned upon by the judge and the other parties in the proceedings. For example, fighting too hard the examining magistrate's decisions during the investigation is often seen as a hazard to the interests of one's client, because the magistrate might turn against you. One of our interviewees reported that, in a murder case in which his client claimed he was innocent, he went on the scene of the crime, alone, after the official seals had been lifted, to see for himself how the place was furnished, measure some distances between objects, and try to understand the perspectives and vantage points of participants in the crime. But he was later reprimanded by the other parties because by going on the crime scene he had doubted the work carried out by the police, one party even reminding him that he was not in the U.S. ${ }^{42}$

For the same reason, attorneys would rather not represent ideas that are deemed to be too extreme, like the notion that DNA evidence could actually be fallible and that the scientist (chosen by the magistrate) might have made a mistake. They are afraid that they would lose their credibility and endanger their client's cause if they adopted such positions:

[Referring to a client suspected of burglary] How do you explain that you find the DNA of this guy from Eastern Europe in a burglarized house in a small village in a rural area of Switzerland? As an attorney, there are limits to what you are willing to defend (S9)

Denying the obvious in front of a professional judge is like shooting yourself in the foot (S11)

These quotations also mark a certain distance and detachment between the attorney and her client, in the sense that the attorney retains a professional

41 Until 2002, a lawyer admitted to the bar of one canton could not practice in another canton without being authorized to do so. Scientific experts who work in bigger cities (like Zurich) report that attorneys coming from outside the canton are more aggressive towards them during the hearings, maybe because they are less inhibited than their local colleagues.

42 See also Field and West (2003). The authors report rarely seeing any evidence of (French) attorneys engaging in private investigations; such behavior would be regarded with suspicion in the French criminal context also. The same authors underline the cultural resistances among attorneys to do anything else than "pleading the file"; they consider it the duty of the state, rather than their own, to gather the raw material of the case. 
duty (and sense of honor) that sets her apart from her client's desires and goals. ${ }^{43}$ Some attorneys are well aware that they tend to avoid confrontation with the examining magistrate, and regret it under some circumstances:

Maybe it's the wrong reaction, to be so prudent, not to dig. In a case of financial criminality, we had that document and the question was to know when it had been written. We had experts who said that they could try to help determine the moment when that document had been created, but the examining magistrate refused [to commission an expert], and it didn't cross our minds to ask a private expert to do it (S6)

It follows from such consensualism that all stages of the proceedings are very predictable. There are hardly ever any surprises, because the existence of an official investigation and official case file renders surprises difficult, but also because no one wants to disrupt the consensualism of the proceedings and risk displeasing the investigating magistrate or the court. This predictability in turn explains one of the characteristics of Swiss attorneys when it comes to evaluating scientific evidence: contrary to American attorneys who feel they need to be ready for anything when they go to trial, their Swiss counterparts already know what will happen, what witnesses will be called, what material evidence will be presented, what the theory of the prosecution is, and what role the scientific evidence (and thus the expert reports) will play in the whole case. Under such circumstances, they consider there is no need to prepare for a "coup de théâtre". That predictability maintains them in a form of passivity and fuels their trust in scientists, which are two other specificities of Swiss attorneys, as we shall see in the next two sections.

The American criminal defense lawyers appeared to have a very different view of their role in the justice system. They see themselves as fighters engaged in a one-sided battle with powerful foes (prosecutors) who were often misguided and sometimes unscrupulous.

[Prosecutors] make presentations that are often skewed and biased towards guilt instead of the honest presentation of what the evidence says (A5).

By their account, they are the sole check on an uncaring, overly-punitive, errorprone justice system that is likely to run amuck if not strenuously resisted. They see criminal defense as a vital function regardless of the client's guilt.

43 On the greater distance between European attorneys and their clients when compared to American attorneys and their clientele and how it impacts their attitudes and behaviors, see van Kessel (1991, pp. 444-445). 
...even if my client says he did it, if he wants a trial in the American justice system we stand up in front of the jury and we tell them that he's not guilty and the state has to prove it (A2).

They expressed no interest in maintaining a chummy, consensual relationship with prosecutors and judges. While they clearly wanted to be taken seriously by prosecutors and judges, they hoped to be respected for their knowledge and ability. By their account, they gained leverage with prosecutors not by being nice and cooperative, but by showing that they could successfully challenge prosecution evidence and thereby damage prosecutors' cases. For example, in describing a case in which she had exposed a serious problem with the state's DNA evidence during pre-trial investigations, one declared:

I embarrassed them so much that they did not call an expert to trial (A6)

\subsubsection{Passivity versus activity and creativity}

For Swiss attorneys, DNA is a powerful form of evidence that cannot be contested. As such, it fundamentally alters the role of the defense attorney in the criminal justice process: DNA delivers a final judgment that renders all contextualization, mitigation or nuance superfluous. Their attitude toward DNA evidence was one of passive acceptance:

I must say it is rare to have the opportunity to challenge scientific evidence (S1)

This statement implies that the "opportunity to challenge" the evidence depends on something other than the lawyer's decision to seize it. When might the "opportunity to challenge" arise? According to the lawyers, the occasion for challenge will arise only if the client can make a credible claim of innocence:

If I had a client who screamed his innocence, or contrary elements, like two witnesses saying "that's not true, you may have his DNA but at the time he was in the U.S.", where there is an obvious mistake, I never had such a case, but then I have no trouble imagining a judge saying "we need to get rid of that doubt" (S12)

But several times, Swiss attorneys mentioned that DNA was a way for them to test their client and know whether she was being truthful with them:

I compare the piece of scientific evidence to what the client tells me. Is it logical? It will influence my evaluation of the client's credibility. Does she think I am an idiot? If not, I'll help her. If yes, she can sort it out herself (S1) 
Here, the client appears as a partner whom one must be able to trust, and if she violates that trust, she is not worth helping. DNA evidence plays the role of liedetector in this context. It is not the position of the client that will determine how one handles DNA evidence, but it is the DNA evidence that determines the attorney's attitude toward her client.

This idea is completely absent in the discourse of American attorneys, who do not seem to care about the position adopted by their client or her truthfulness, and who will evaluate the DNA evidence no matter what:

We [examine the reliability of DNA evidence] always as a matter of principle (A1)

If my client admits something, I will still look into the DNA to double check, because [the client's statements] are not overwhelming evidence, cops can twist words, they can give false confessions, people can be mistaken... (A6)

One American attorney challenged the DNA evidence linking his client to the gun in a murder case in spite of the fact that there was a video tape of his client committing the crime. The client was convicted on the basis of the video, but the lawyer proudly claimed to have successfully challenged the evidence linking the client to the DNA found on the gun. This is an extreme example of the difference in positions between Swiss and American attorneys when DNA is used to incriminate their client. But some American attorneys are less absolute in their approach:

Whether I decide to look more thoroughly at DNA in a given case depends on the issues. If it's a rape case and the guy says it was consensual or if there are witnesses who say that he was there it doesn't seem useful to mess around too much with the DNA. There are times when the DNA evidence really doesn't matter all that much, the identity is not going to be the issue. If ID is the issue, DNA is critical and you have (emphasized by the interviewee) to look at it (A10)

This difference between passive Swiss attorneys and more active American attorneys is also visible in the density of the material they request to perform their review of DNA evidence. The documents transmitted by a Swiss DNA analyst to the investigating magistrate, and to which the attorneys will have access, usually only consist of a brief (2-3 pages) report of the findings. Swiss law allows the investigating magistrate, the court or the parties to request further information (articles 187, 189 CPP), but the people interviewed had never heard of a single case in which that possibility had been used. This does not mean that they are happy with the reports though: some of them complained that the reports did not contain the information they needed to check when the analysis had been done, for example, with regards to a sequence of events in the case. Others wished they knew more about the 
technical aspects of the analysis, but complained that "the judge never asks the experts such questions" (S4), maybe forgetting that the law allows him to seek further precisions, or, more probably, not wishing to interfere in what he basically sees as the investigating magistrate's prerogative.

For the elite American lawyers that we interviewed, a full examination implies getting, besides the final report, all the previous versions of the report, the laboratory notes, the electropherogram, the communication file, the quantitation sheet, the standard curve, the amplification set up page, the documents about sample dilution and concentration, the injection list, the state match detailed report, the allele chart, the population statistics, the checklist for serology and DNA, the analyst request form, the evidence sheet, the custody report, the raw data, the analyst's proficiency test results, the contamination or incidence logs of the laboratory and specific expert.

I think it's important for lawyers to know that there is a file out there, I think it's important for them to read the file, I mean, any lawyer can read the case notes that say "bloodlike substance on the outside of the envelope" (A2, referring to a case in which she found blood on an envelope containing items that had no blood on them, suggesting a possible contamination)

Implied here is that it doesn't take scientific education to make interesting discoveries in the expert's material.

Passivity among defense attorneys has been reported in other non-adversarial jurisdictions. One observer gave many illustrations of French defense counsel's passivity in a murder case she sat on, on occasions when a reaction would have been warranted (in her opinion at least). Asked about it, the French defense lawyers replied that they were afraid to annoy or to irritate the judge if they intervened (Lerner, 2001). Discussing Western Europe more generally, two other scholars remarked: "Defense counsel is particularly inactive" (Goldstein \& Marcus, 1977, p. 265).

\subsubsection{Trust in the expert and her results versus mistrust}

Our Swiss and American respondents also differed in the level of trust they placed in experts and their analytical results. ${ }^{44}$ The American attorneys seem to take nothing for granted when it comes to DNA expert reports. They emphasized

44 It is difficult to differentiate between trust towards the expert as a person and trust towards the analytical results; usually, one element entails the other, even if their bases are distinct. 
the importance of looking beyond laboratory reports and examining the laboratory case file, the analyst's bench notes, and other such materials.

You start with the lab notes, and then, if you spot strange things, you request more, always more (A4).

Swiss experts, on the other hand, said they accepted what the laboratory report says:

I don't have a choice, I have to trust the expert, I can't know it if what he says is nonsense (S1)

As to the DNA analysis itself [as opposed to the relevance of the evidence collected], we have to trust them $(\mathrm{S} 12)$

Again, passivity appears as a key feature in these quotations: the absence of choice, the necessity to trust; it seems that some Swiss attorneys feel helpless. Others are more straightforward, though, and admit that their position is voluntary:

[Asked whether in a given case he would request more information from the expert who had reported a DNA match] no, I won't request anything, I want to believe that they did their job properly (S13)

Swiss attorneys also expect magistrates to trust the scientist and the DNA:

For judges, DNA is the absolute proof (...) they cannot imagine that there might be a mistake, especially when the expert comes and says "I did all the analyses twice" (S10)

One interesting element of epistemology was given by one of the interviewees:

Judges are even in a worse position than attorneys to understand expert reports, because at least we see how the expert report comes into existence, we see what questions are asked, how knowledge is built out of the different elements of the case, whereas the judge, he only sees the final product, he does not understand it the way we understand it (S2)

This attorney apparently did not realize that close examination of the DNA evidence might produce meaningful insights into how it was constructed from human thoughts and human actions, too.

Trust entails several aspects: the idea that the scientist is competent, that she is honest and unbiased, and that the techniques she employs to produce the analytical results are reliable. In the words of one very optimistic Swiss attorney:

Swiss experts are the best in the world (S15)

Another nuanced the idea, and mentioned its direct consequence: 
An authority-appointed expert is usually neutral, which means that you show restraint toward him (S7)

The belief in the neutrality of the expert is also mediated through the belief that DNA analysis produces results that are “objective”, as we have seen previously. No interpretation is possible, so that the person of the expert carrying out the analysis does not really matter. When you combine these two elements, a belief that the expert is neutral and competent, and the idea that DNA produces results that are unquestionable, you understand the attitude of Swiss attorneys toward DNA evidence.

Trust towards experts and their results manifests itself in several different ways: first, defense attorneys seldom ask any additional questions from the expert once his report has been added to the file, or when he testifies in court. This is supported by a statement made by a Swiss prosecutor in a previous study (Vuille, 2011): "Results reported by the expert could be challenged, but attorneys [from our canton] are not like that, they trust the seriousness with which authorities [from our canton] carry out their work." Yet, defense attorneys make ample use of that right (guaranteed by articles 188 and 189 CPP) when psychiatrists are heard, for example. Second, when questions are asked, they remain very superficial or basic.

What is problematic is that this trust is uninformed. A certain amount of trust is unavoidable as the scientist is commissioned precisely because of her specialized knowledge in a given field. But the trust should not be blind. The defense lawyers should evaluate expert opinions critically. No one else in the system plays this skeptical role and, as discussed earlier, a certain degree of skepticism is surely warranted.

\section{Discussion and conclusions}

Our research examined small groups of Swiss and American lawyers. We do not think (nor do we suggest) that these participants are representative of defense lawyers in general in the two countries. Rather, we think they represent elite practitioners. What we have learned is how the top criminal defense practitioners in the two countries, who represent the state-of-the art, think about DNA evidence and how they report dealing with it.

We had no difficulty finding American defense lawyers who were "DNA specialists." We conducted detailed interviews with only eleven of these lawyers, but the strong consistency of responses among our American respondents - who all told us the same things - convinced us that we have a good fix 
on how American lawyers who are "DNA specialists" view and respond to DNA evidence.

We found no "DNA specialists" among Swiss defense lawyers. Given our knowledge and contacts in the Swiss legal system, we think it is unlikely that there are Swiss lawyers who are much more knowledgeable about DNA evidence, or more active in examining and challenging it, than the practitioners we interviewed. With respect to this topic, we think our respondents represent the best the Swiss defense bar had to offer at the time of the interviews.

The elite American lawyers we interviewed knew far more about DNA evidence. They described impressively energetic efforts to gain access to relevant underlying materials and obtain expert assistance in order to perform a comprehensive evaluation of the strengths and limitations of the DNA evidence in their cases. They reported frequent success in exposing problems and forcing the government's experts to alter, moderate or withdraw conclusions. Even allowing for a certain amount of exaggeration and over-claiming, it seems indisputable that they dealt with DNA evidence that incriminated their clients far more effectively than did their Swiss counterparts. While they sometimes elected not to challenge it in court (on grounds that the DNA test results were clear-cut and indisputable), these decisions were reached after a careful evaluation of the evidence to assess its merits. The Swiss lawyers, by contrast, assumed that DNA evidence is indisputable in every case and responded accordingly.

Our review of the scientific literature on forensic DNA testing suggests that the skeptical and vigilant approach of the Americans is more appropriate than the sanguine passivity of the Swiss. Hence, in our view, the performance of the American defense lawyers was superior to the performance of the Swiss.

As already mentioned, we realize, of course, that there is great variation in the quality of legal representation afforded to criminal defendants in the United States. We do not claim that the elite practitioners we interviewed represent defense lawyers in general. Indeed, there is considerable evidence that they do not. Consider, for example, the debacle of the Houston Police Department Crime Laboratory that came to light in 2003 through the efforts of investigative journalists. A comprehensive review revealed that the laboratory had engaged in substandard procedures for DNA and serological testing for over a decade (Bromwich, 2007). The laboratory routinely failed to include critical controls when performing assays and routinely presented statistical conclusions that grossly overstated the value of the resulting evidence. In some cases they misstated or misrepresented test results. The persistence of these egregious practices represented not just a failure of the laboratory, but a failure of the legal system. The defense lawyers whose job it was to examine and evaluate the evidence incriminating their clients were utterly ineffective at exposing the 
problems (Thompson, 2008). They failed to obtain access to laboratory records (that would have made the problems apparent) and failed to obtain expert assistance. Like the Swiss lawyers interviewed in this study, their attitude toward DNA was one of passive acceptance.

While we do not claim that our American respondents are typical of American defense lawyers, we do believe that they represent what is possible in the American system at its best. We have compared the best American defense lawyers against the best Swiss defense lawyers and we conclude that the Americans do a better job evaluating and challenging DNA evidence. The important question to consider is why this is so, and what, if anything, this finding tells us about the American and Swiss legal systems, and perhaps more broadly, about adversarial and non-adversarial systems of justice.

The answer may lie partly in the very different legal cultures of Switzerland and the United States. The Swiss lawyers appear to have greater respect for authority (particularly the scientific authority of DNA evidence) and a strong commitment to a consensual process. They seem reluctant to rock the boat by raising novel challenges. To them it is an insult to behave "like an American" by advocating too aggressively. They seemed reluctant to even consider the idea that DNA evidence could, and should, be challenged. The American lawyers, by contrast, were proud of their ability to rock the boat. They bragged about instances where they had "embarrassed" the prosecution, forced experts to back down, and exposed problems. For them, the direct "in your face" challenge is part of the adversarial game and they took pride in playing that game effectively. Their strong interest in learning about DNA evidence seemed to arise, at least in part, from a desire to challenge it more effectively. They were looking for ammunition to use in their ongoing battles with prosecutors. Becoming DNA specialists made them more formidable and effective.

An alternative theory, worth considering, is that the differences we observed are specific to DNA evidence, rather than being features of the respective legal cultures. Perhaps the Swiss lawyers fail to challenge DNA evidence because they have not yet become educated to its limitations. It is interesting that Swiss lawyers are willing to challenge and engage with psychiatric evidence, while considering DNA sacrosanct. Much of the literature on forensic DNA evidence, and virtually all of the literature that raises criticisms and identifies problems, is published in English. The Swiss lawyers, who are generally fluent in French and German, or Italian, may have lesser facility in English, and thus more difficulty learning about forensic DNA evidence. We do not believe that access to information was the sole problem, however. As noted earlier, the Swiss lawyers did not seem interested in learning more about DNA evidence because they thought it was virtually infallible, or at least unchallengeable. Whether their assumptions 
about DNA evidence could be changed through further education, or are baked into their cultural perspectives, is an issue we cannot at present answer, but one worthy of further research.

Another important question, worthy of additional research, is the extent to which our observations in Switzerland and the United States apply to practices in non-adversarial and adversarial legal systems more generally. Defense challenges to forensic DNA evidence appear to have been far more frequent in nations with adversarial than in nations with non-adversarial legal systems. For example, concerns about the use of "low-template" DNA testing have led to effective challenges to DNA evidence in Britain and Northern Ireland (Gill, 2014; Murphy, 2015; Thompson, Mueller, \& Krane, 2012). Questions about the potential for DNA testing error due to cross-contamination have been raised extensively in Australia and New Zealand (Gill, 2014; Thompson, 2012).

In Continental Europe, challenges to DNA evidence seem to have been rare. One interesting exception was the Italian prosecution of Amanda Knox, where the defense was able to raise a number of important concerns about the way in which DNA test results were interpreted, as well as the potential for inadvertent transfer of DNA from on item to another (Vuille, Biedermann, \& Taroni, 2013). But this exception may help prove the rule. The fact that Knox is an American may have led, uncharacteristically, to an American-style defense in an Italian case. Lawyers for Knox drew on American DNA experts to help analyze and critique the evidence, which then led to international discussions among DNA experts on the value of the evidence adduced in the case. The success of the defense in raising important concerns about the evidence against Knox illustrates the utility of raising an American style defense to Italian DNA evidence. That such a challenge to DNA evidence should arise precisely in Italy is also intriguing: a non-adversarial country for many decades, Italy changed the structure of its criminal justice system in 1988 and adopted many features of the adversarial systems found in AngloAmerican jurisdictions. Could this suggest that adversarial systems offer better opportunities for challenging evidence than non-adversarial systems? Or could it suggest that adversarial systems present a higher risk of producing misleading or ambiguous DNA results in the first place? These questions remain open.

The Swiss lawyers we interviewed prided themselves on not being like the Americans that they have seen in media depictions of American trial practice. While we respect their norms of civility, we have come to believe that the Swiss system, and perhaps other non-adversarial systems, could benefit if defense lawyers were a bit more like the Americans in how they deal with forensic DNA evidence. 
Acknowledgements: The authors thank the Swiss National Science Foundation for supporting the first author during this project (grants PBLAP1-136958 and PBLAP1-145850). Preliminary findings were presented at the Socio-Legal Studies Workshop at the University of California, Irvine Law School on September 27, 2013. The article benefitted from comments of workshop participants. During the period when the article was finalized, the second author was a visitor at the Isaac Newton Institute for Mathematical Sciences as part of the program Probability and Statistics in Forensic Science which was supported by EPSRC Grant Number EP/K032208/1. We thank the Institute for its hospitality.

Funding: University of California Laboratory Fees Research Program (Award ID\# 12-LR-237268) Swiss National Science Foundation (Grant / Award Number: 'PBLAP1-136958', 'PBLAP1-145850').

\section{References}

Alldridge, P. (1999). Scientific Expertise and Comparative Criminal Procedure. International Journal on Evidence \& Proof, 3(3), 141-164.

Alschuler, A. W. (1997). How to Win the Trial of the Century: The Ethics of Lord Brougham and the 0J Simpson Defense Team. McGeorge Law Review, 29, 291-321.

Aronson, J. D. (2007). Genetic Witness, Science, Law and Controversy in the Making of DNA

Profiling. New Brunswick, NJ; London: Rutgers University Press.

Bohnet, F., \& Martenet, V. (2009). Droit de la profession d'avocat. Berne: Stämpfli.

Bradley, C. M. (1996). The Convergence of the Continental and the Common Law Model of Criminal Procedure. Criminal Law Forum, 7, 471-484.

Brants, C. (2008). The Vulnerability of Dutch Criminal Procedure to Wrongful Conviction. In C. R. Huff \& M. Killias (Eds.), Wrongful Conviction, International Perspectives on Miscarriages of Justice (pp. 157-182). Philadelphia: Temple University Press.

Broeders, T. (2003). The Role of the Forensic Expert in an Inquisitorial System. In P. van Koppen \& S. Penrod (Eds.), Adversarial versus Inquisitorial Justice (pp. 245-253). New York: Kluwer.

Bromwich, M. (2007). Final Report of the Independent Investigator for the Houston Police Department Crime Laboratory and Property Room. Washington, DC: Fried, Frank, Harris, Shriver \& Jacobson LLP.

Burnand, Y. (2004). Liberté de la preuve et intime conviction. Revue jurassienne de jurisprudence, 1, 89-122.

Butler, J. M. (2010). Fundamentals of Forensic DNA Typing. New York: Elsevier.

Champod, C., \& Vuille, J. (2011a). "Pas vraiment votre honneur...": vademecum de la communication entre experts forensiques et magistrats. In M. Jendly \& M. A. Niggli (Eds.), Système pénal et discours publics: entre justice câline et justice répressive (pp. 227-242). Berne: Stämpfli. 
Champod, C., \& Vuille, J. (2011b). Scientific Evidence in Europe - Admissibility, Evaluation and Equality of Arms. International Commentary on Evidence, 9(1), 1-68.

Daly, D. J., Murphy, C., \& McDermott, S. D. (2012). The transfer of touch DNA from hands to glass, fabric and wood. Forensic Science International: Genetics, 6, 41-46.

Damaška, M. R. (1973). Evidentiary Barriers to Conviction and Two Models of Criminal Procedure: A Comparative Study. University of Pennsylvania Law Review, 121(3), 506-589. Damaška, M. R. (1995). Free Proof and Its Detractors. The American Journal of Comparative Law, 43(3), 343-357.

Damaška, M. R. (1997). Evidence Law Adrift. New Haven: Yale Univ Press.

de Keijser, J. W., Maisch, M., Leuning, E. T., Weulen Kranenbarg, M., \& Lenssen, D. (2016). Differential reporting of mixed DNA profiles and its impact on jurists' evaluation of evidence: An international analysis. Forensic Science International: Genetics, 23, 71-82.

Dror, I. E., \& Hampikian, G. (2011). Subjectivity and Bias in Forensic DNA Mixture Interpretation. Science \& Justice, 51(4), 204-208.

Field, S., \& West, A. (2003). Dialogue and the Inquisitorial Tradition: French Defence Lawyers in the Pre-Trial Criminal Process. Criminal Law Forum, 14(3), 261-316.

Flick, U. (2009). An Introduction to Qualitative Research (4th ed.). Thousand Oaks: Sage.

Fonnelop, A.E., Egeland, T., \& Gil, P. (2015). Secodary and Subsequent DNA Transfer During Criminal Investigation. Forensic Science International, 17, 155-162.

Frase, R. S. (1990). Comparative Criminal Justice as a Guide to American Law Reform: How Do the French Do It, How Can We Find Out, and Why Should We Care? California Law Review, 78(3), 539-683.

Frase, R. S., \& Weigend, T. (1995). German Criminal Justice as a Guide to American Law Reform: Similar Problems, Better Solutions. Boston College International \& Comparative Law Review, $18,317$.

Gibbs, G. R. (2007). Analyzing Qualitative Data. Los Angeles, London, New Dehli, Singapore: Sage.

Gill, P. (2014). Misleading DNA Evidence: Reasons for Miscarriages of Justice. New York: Elsevier.

Glaser, B. G., \& Strauss, A. L. (2008 [1967]). The Discovery of Grounded Theory: Strategies for Qualitative Research. New Brunswick: Aldine Transaction.

Goldstein, A. S. (1973). Reflections on Two Models: Inquisitorial Themes in American Criminal Procedure. Standford Law Review, 26, 1009.

Goldstein, A. S., \& Marcus, M. (1977). The Myth of Judicial Supervision in Three "Inquisitorial" Systems: France, Italy and Germany. The Yale Law Journal, 87(2), 240-283.

Goray, M., \& van Oorshat, R. (2015). The Complexities of DNA Transfer During a Social Setting. Legal Medicine, 17(2): 82-91.

Havard, J. D. J. (1992). Expert Scientific Evidence Under the Adversarial System, A Travesty of Justice? Journal of the Forensic Science Society, 32(3), 225-235.

Huff, C. R., \& Killias, M. (2008). Wrongful Convictions, Conclusions from an International Overview. In C. R. Huff \& M. Killias (Eds.), Wrongful Conviction, International Perspectives on Miscarriages of Justice (pp. 287-300). Philadelphia: Temple University Press.

Jackson, J. D. (2005). The Effect of Human Rights on Criminal Evidentiary Processes: Towards Convergence, Divergence or Realignment? The Modern Law Review, 68(5), 737-764.

Jescheck, H.-H. (1970). Principles of German Criminal Procedure in Comparison with American Law. Virginia Law Review, 56, 239-253. 
Jositsch, D. (2013). Grundriss des schweizerischen Strafprozessrechts (2nd ed.). Zurich/St-Gall: Dike.

Kaufmann, J. -C. (2004). L'entretien compréhensif. Paris: Armand Colin.

Kaye, D. H. (2010). The Double Helix and the Law of Evidence. Cambridge: Harvard University Press.

Kvale, S. (2007). Doing Interviews. Los Angeles, London, New Delhi, Singapore: Sage.

Langbein, J. H. (1977). Comparative Criminal Procedure: Germany. St-Paul, MN: West Publishing Co.

Langbein, J. H. (1981). Mixed Court and Jury Court: Could the Continental Alternative Fill the American Need? Law \& Social Inquiry, 6(1), 195-219.

Langbein, J. H., \& Weinreb, L. L. (1978). Continental Criminal Procedure: "Myth" and Reality. Yale Law Journal, 87(8), 1549-1569.

Lerner, R. L. (2001). The Intersection of Two Systems: An American on Trial for an American Murder in the French Cour D'Assises. University of Illinois Law Review, 791.

Lind, E. A., Thibaut, J., \& Walker, L. (1973). Discovery and Presentation of Evidence in Adversary and Nonadversary Proceedings. Michigan Law Review, 71, 1129-1144.

Lind, E. A., \& Walker, L. (1979). Theory Testing, Theory Development, and Laboratory Research on Legal Issues. Law and Human Behavior, 3, 5-20.

Lynch, M., Cole, S., McNally, R., \& Jordan, K. (2008). Truth Machine, The Contentious History of DNA Fingerprinting. Chicago/London: The University of Chicago Press.

Margot, P. (1998). The Role of the Forensic Scientist in an Inquisitorial System of Justice. Science \& Justice, 38(2), 71-73.

Meintjes-van der Walt, L. (2001). Expert Evidence in the Criminal Justice Process - A Comparative Perspective. Amsterdam: Rozenberg.

Miles, M. B., \& Huberman, A. M. (2003). Analyse des données qualitatives (M. H. Rispal, Trans. 2ème ed.). Bruxelles: de Boeck.

Murphy, E. (2015). Inside the Cell: The Dark Side of Forensic DNA. New York: Nation Books.

Oberholzer, N. (2012). Grundzüge des Strafprozessrechts (3rd ed.). Berne: Stämpfli.

Pizzi, W. T. (1997). The American “Adversary System"? West Virginia Law Review, 100, 847-852.

Pizzi, W. T. (2000). Trials Without Truth: Why our System of Criminal Trials has Become an Expensive Failure and What We Need to do to Rebuild it. New York: New York University Press.

Poy, A. L., \& van Oorshot, R. (2006). Trace DNA Presence, Origin, and Transfer with a Forensic Biology Laboratory and Its Potential Effect on Casework. Journal of Forensic Identification, 56(4): 558-576.

President's Council of Advisors on Science and Technology (PCAST). (2016). Forensic Science in Criminal Courts: Ensuring Scientific Validity of Feature-Comparison Methods; https://www. whitehouse.gov/administration/eop/ostp/pcast/docsreports

Quivy, R., \& Van Campenhoudt, L. (1995). Manuel de recherche en sciences sociales (2ème ed.). Paris: Dunod.

Redmayne, M. (2001). Expert Evidence and Criminal Justice. Oxford: Oxford University Press.

Riklin, F. (1998). Zu den Auswirkungen einer eidgenössisch vereintlichten Strafprozessordnung auf die kantonale Behördenorganisation. In Solothurner Festgabe zum schweizerischen Juristentag 1998 (pp. 641-655). Solothurn: Solothurnischen Juristenverein.

Rubin, H. J., \& Rubin, I. S. (2005). Qualitative Interviewing: The Art of Hearing Data (2nd ed.). Thousand Oaks: Sage. 
Saks, M. J. (2003). Expert Witness in Europe and the United States. In P. van Koppen \&

S. Penrod (Eds.), Adversarial versus Inquisitorial Justice (pp. 235-244). New York: Kluwer.

Schlesinger, R. B. (1976). Comparative Criminal Procedure: A Plea for Utilizing Foreign

Experience. Buffalo Law Review, 26, 361.

Sevier, J. (2014). The Truth-Justice Tradeoff: Perceptions of Decisional Accuracy and Procedural Justice in Adversarial and Inquisitorial Legal Systems. Psychology, Public Policy \& Law, 20, 212-249.

Sheppard, B. H., \& Vidmar, N. (1980). Adversary Pretrial Procedures and Testimonial Evidence: Effects of Lawyer's Role and Machiavellianism. Journal of Personality and Social Psychology, 39, 320-332.

Silverman, D. (2005). Doing Qualitative Research (2nd ed.). Los Angeles: Sage.

Silverman, D. (2006). Interpreting Qualitative Data (3rd ed.). Los Angeles: Sage.

Slobogin, C. (2013). Lessons from Inquisitorialism. Public Law and Legal Theory Working Paper Number 13-36.

Song, Y. S., Patil, A., Murphy, E. E., \& Slatkin, M. (2009). Average Probability that a "Cold Hit" in a DNA Database Search Results in an Erroneous Attribution. Journal of Forensic Sciences, 54(1), 22-27.

Spencer, J. R. (1992). Court Experts and Expert Witnesses, Have we a Lesson to Learn from the French? Current Legal Problems, Part 2: Collected Papers, 45, 213-236.

Thibaut, J., \& Walker, L. (1975). Procedural Justice: A Psychological Analysis. Hillsdale, NJ: Lawrence Erlbaum Associates.

Thibaut, J., \& Walker, L. (1978). A Theory of Procedure. California Law Review, 66, 541-566.

Thompson, W. C. (2006). Tarnish on the "Gold Standard": Understanding Recent Problems in Forensic DNA Testing. The Champion, 30(1), 10-16.

Thompson, W. C. (2008). Beyond Bad Apples: Analyzing the Role of Forensic Science in Wrongful Convictions. Southwestern University Law Review, 37, 971-994.

Thompson, W. C. (2009). Painting the Target Around the Matching Profile: The Texas Sharpshooter Fallacy in Forensic DNA Interpretation. Law Probability and Risk, 8(3), 257-276.

Thompson, W. C. (2012). Forensic DNA Evidence, the Myth of Infallibility. In S. Krimsky \& J. Gruber (Eds.), Genetic Explanations: Sense and Nonsense. Harvard: Harvard University Press.

Thompson, W. C., Mueller, L., \& Krane, D. E. (2012). Forensic DNA Statistics: Still Controversial in Some Cases. The Champion. (December), pp. 12-23.

van Kampen, P. T. C. (1998). Expert Evidence Compared, Rules and Practices in the Dutch and American Criminal Justice System. Antwerpen/Groningen: Intersentia Rechtswetenschappen.

van Kampen, P. T. C. (2003). Expert Evidence, the State of the Law in the Netherlands and the United States. In P. J. van Koppen \& S. D. Penrod (Eds.), Adversarial versus Inquisitorial Justice: Psychological Perspectives on Criminal Justice Systems (pp. 209-234). New York: Kluwer.

van Kessel, G. (1991). Adversary Excesses in the American Criminal Trial. Notre Dame Law Review, 67, 403.

van Koppen, P. (2008). Blundering Justice, The Schiedam Park Murder. In R. Kocsis (Ed.), Serial Murder and the Psychology of Violent Crimes (pp. 207-228). Totowa, N): Humana Press. 
van Koppen, P. J., \& Penrod, S. D. (2003). Adversarial or Inquisitorial: Comparing Systems. In P. J. van Koppen \& S. D. Penrod (Eds.), Adversarial versus Inquisitorial Justice: Psychological Perspectives on Criminal Justice Systems (pp. 1-19). New York: Kluwer.

Volkmann-Schluck, T. (1981). Continental European Criminal Procedures: True or Illusive Model? American Journal of Crime Law, 9, 1.

Vuille, J. (2011). Ce que la justice fait dire à l'ADN (et que l'ADN ne dit pas vraiment): étude qualitative de l'évaluation de la preuve par $A D N$ dans le système judiciaire pénal suisse Lausanne: Ecole des Sciences Criminelles.

Vuille, J. (2013). Admissibility and Appraisal of Scientific Evidence in Continental Europe Criminal Justice Systems: Past, Present and Future. The Australian Journal of Forensic Science, 45(4), 1-9.

Vuille, J., Biedermann, A., \& Taroni, F. (2013). The Importance of Having a Logical Framework for Expert Conclusions in Forensic DNA Profiling, Illustrations from the Amanda Knox Case. In C. R. Huff \& M. Killias (Eds.), Wrongful Convictions and Miscarriages of Justice, Causes and Remedies in North American and European Criminal Justice Systems (pp. 137-159). New York: Routledge.

Vuille, J., \& Taroni, F. (2011). L'article 184 al. 3 CPP, une fausse bonne idée du législateur? Revue pénale suisse, 129(2), 164-179.

Weinreb, L. L. (1977). Denial of Justice: Criminal Process in the United States. New York: Free Press.

Wicki, F. (2011). Einleitung. In M. A. Niggli, M. Heer, \& H. Wiprächtiger (Eds.), Schweizerische Strafprozessordnung, Basler Kommentar (pp. 3-17). Bâle: Helbing Lichtenhahn.

Willis, S. (2009). Forensic Science, Ethics and Criminal Justice. In J. Fraser \& R. Williams (Eds.), Handbook of Forensic Science (pp. 523-545). Cullompton, UK: Willan Publishing.

Zoppis, S., Muciaccia, B., D’Alessio, A., Ziparo, E., Vecchiotti, C., \& Filippini, A. (2014). DNA Fingerprinting Secondary Transfer From Different Skin Areas: Morphological and Genetic Studies. Forensic Science International: Genetics 11, 137-143. 